\title{
Review of GTAW Welding Parameters
}

\author{
Bolarinwa Johnson Kutelu1, Saliu Ojo Seidu², Godwin Idenala Eghabor², \\ Ayotunde Idris Ibitoye ${ }^{2}$
}

\footnotetext{
${ }^{1}$ Department of Minerals and Petroleum Resources Engineering, Federal Polytechnic, Ado Ekiti, Nigeria ${ }^{2}$ Department of Metallurgical and Materials Engineering, Federal University of Technology, Akure, Nigeria Email: seidu2@yahoo.co.uk
}

How to cite this paper: Kutelu, B.J., Seidu, S.O., Eghabor, G.I. and Ibitoye, A.I. (2018) Review of GTAW Welding Parameters. Journal of Minerals and Materials Characterization and Engineering, 6, 541-554. https://doi.org/10.4236/jmmce.2018.65039

Received: March 27, 2018

Accepted: August 28, 2018

Published: August 31, 2018

Copyright ( 92018 by authors and Scientific Research Publishing Inc. This work is licensed under the Creative Commons Attribution International License (CC BY 4.0).

http://creativecommons.org/licenses/by/4.0/ (c) (i) Open Access

\begin{abstract}
Welding as a fabrication process is one of the vital production routes for most manufacturing industries. Several factors are involved in the choice of welding process for specific applications; notable among these are compositional range of the material to be welded, the thickness of the base materials and type of current. Most metals oxidize rapidly in their molten state, and therefore, the weld area needs to be protected from atmospheric contamination; this is achieved in gas tungsten arc welding GTAW by a shielding gas (argon, helium, nitrogen). GTAW technique is one of the major processes for joining austenitic stainless steels (ASS) and ferritic stainless steel (FSS) fabrication. However, the microstructural change that occurs during welding and at weld joint is still a major challenge today as it affects both the corrosion resistance and the mechanical properties. Therefore, this present paper reviews past research findings on GTA welding of ASS and FSS. Results of the findings have confirmed that, depending on the amount of heat input, which can be controlled by welding parameters (welding speed, voltage and current), welded joints particularly, heat affected zones (HAZs) of both grades of steels can undergo mechanical failure and can be susceptible to corrosion attack if the joints are produced with a less ideal combination of welding parameters.
\end{abstract}

\section{Keywords}

Austenitic Stainless Steel (ASS), GTA Welding, Heat Affected Zone (HAZ), Welding Speed, Voltage, Current, Heat Input, Shielding Gas, Filler Metal

\section{Introduction}

Welding is a process involving the joining of two crystalline work pieces usually of metal by bringing their fitted surfaces into such intimate contact that crystal-to-crystal bonding occurs. Depending on the welding techniques, heat re- 
quired for welding can be obtained from a burning gas or an electric arc, or generated by electric resistance [1]. The fitted surfaces may melt together, or a filler rod may melt between them to form a connecting bridge. Area of industrial applications is seen in buildings, bridges, ships, pressure vessels and nuclear reactors among others [2]. The increasing use of welding in these areas is predicated upon its many advantages such as design flexibility, economy (cost savings), reduced overall weight and enhanced structural performance [3] [4]. Based on the heat source, fusion welding is divided into gas, arc and high-energy beam welding. In arc welding, energy is transferred from the welding electrode to the base metal by an electric arc; upon starting the arc, a sufficient amount of power (energy transferred per unit time) and energy density is supplied to the electrode. Both the base metal and the filler metal are melted to create the weld [5] [6].

Gas Tungsten Arc Welding (GTAW) also referred to as Tungsten Inert Gas (TIG) uses a non-consumable tungsten electrode to produce the weld. Under the correct welding conditions, the tungsten electrode does not melt. It operates by creating an electric arc between the tungsten electrode and the work piece; the electric arc can produce temperatures of up to $19,400^{\circ} \mathrm{C}$ [7]. In GTAW, weld can be made with or without filler metal. When filler metal is used, it is added directly into the molten pool by dipping the end of a filler rod into the leading edge of the molten weld pool, when filler metal is not used, edges of the metal are heated, melted and flowed together by themselves, and as the molten metal cools, coalescence occurs and the parts are joined, resulting in weld requiring minimum finishing [8] [9]. The common use of GTAW as components assembling technique has been linked to its high quality welds, which is attributable to high degree of control of heat input and filler additions. GTAW has found wide appreciation in areas where precision welding is required, notable among which included atomic energy, aircraft, chemical and instrument industries, nuclear industry, food industry, maintenance and repair work and some manufacturing areas [10]. Also, GTA welding is widely utilized for the joining of high strength, reactive metals and alloys such as stainless steel, aluminium and magnesium alloys [11] [12]. In addition, copper, brass, titanium, nickel and nickel alloys, stainless steel, inconel, high temperature and hard surfacing alloys like zirconium, titanium have been successfully welded with the GTA welding techniques [13].

GTAW is especially suited for thin metals, metals ranging from sheet metal up to $1 / 4$ in including expansion bellows, transistor cases, instrument diaphragms and can-sealing joints. GTAW has been utilised for rocket motor chamber fabrications in launch vehicles. It can weld in all positions to produce smooth and sound welds with fewer spatters. However, if tungsten is transferred to molten weld pool during welding, it contaminates the weld; tungsten inclusion is hard and brittle. Also, weld metal contamination can occur if by chance, filler rod end comes out of the inert gas shield [14]. Toughness and resistance of the welded piece to failure is dependent on many factors such as welding parameters (cur- 
rent, voltage, speed etc.), geometric shape, design of the welding piece, the method implemented for welding and the nature of the applied stresses and others [15]. Low productivity, relative shallow penetration and high sensitivity of the surface condition and chemical composition of the base metal are some of the disadvantages associated with GTAW process [16].

\subsection{Primary GTAW Process Parameters}

\subsubsection{Welding Current}

Welding current is the most influential variable in arc welding process which controls the electrode burn off rate, the depth of fusion and geometry of the weldments. Current has direct influence on weld bead shape, on welding speed and quality of the weld. Most GTAW welds employ direct current on electrode negative (DCEN) (straight polarity) because it produces higher weld penetration depth and higher travel speed than on electrode positive (DCEP) (reverse polarity). Besides, reverse polarity produces rapid heating and degradation of the electrode tip, because anode is more heated than cathode in gas tungsten electric arc. Higher current in GTA welding can lead to splatter and work piece become damage. Again lower current setting in GTA welding lead to sticking of the filler wire. Sometimes larger heat affected area can be found for lower welding current, as high temperatures need to applied for longer periods of time to deposit the same amount of filling materials. Fixed current mode will vary the voltage in order to maintain a constant arc current [17] [18].

\subsubsection{Welding Voltage}

This is the electrical potential difference between the tip of the welding wire and the surface of the molten weld pool. Welding voltage can be fixed or adjustable depending on the GTA welding equipment. It determines the shape of the fusion zone and weld reinforcement. A high initial voltage allows for easy arc initiation and a greater range of working tip distance. However, it produces wider, flatter and less deeply penetrating welds than low welding voltages, depth of penetration is maximum at optimum arc voltage, to high voltage on the other hand will lead to large variable in welding quality [19].

\subsubsection{Welding Speed}

Speed of welding is defined as the rate of travel of the electrode along the seam or the rate of the travel of the work under the electrode along the seam [20]. Weld Travel Speed $=$ Travel of electrode/arc time, $\mathrm{mm} / \mathrm{min}$ [21]. Welding speed is an important parameter for GTAW welding. The effect of increasing the welding speed for the same current and voltage is to reduce the heat input. The welding speed does not influence the electromagnetic force and the arc pressure because they are dependent on the current. The weld speed increase produces a decrease in the weld cross section area, and consequently penetration depth $(D)$ and weld width $(W)$ also decrease, but the $D / W$ ratio has a weak dependence on travel speed. These results suggest that the travel speed does not influence the mechanisms involved in the weld pool formation, it only influences the volume 
of melted material. Normal welding speeds are from 100 to $500 \mathrm{~mm} / \mathrm{min}$ depending on current, material type and plate thickness [22].

\subsubsection{Heat Input}

Heat input is a relative measure of the energy transferred per unit length of weld. The higher the heat input, the slower the cooling rate. Conversely, the lower the heat input, the faster the cooling rate. Hence, like preheat and interpass temperature, heat input is an important characteristic that influences the cooling rate, which may affect the mechanical properties and metallurgical structure of the weld and the HAZ [23]. In arc welding, it is well known that energy is transferred from the welding electrode to the base metal by an electric arc. Upon starting the arc, sufficient amount of power (energy transferred per unit time) and energy density is supplied to the electrode. Consequently, both the base metal and the filler metal are melted to create the weld [10] [24]. Heat input is typically calculated as the ratio of the power (i.e., voltage $\times$ current) to the velocity of the heat source (i.e., the arc). Heat input was calculated according to equation 1

$$
H=\frac{x I X V}{v}
$$

where, $H=$ heat input in $\mathrm{KJ} / \mathrm{mm}$,

$$
\begin{aligned}
& \eta=\text { efficiency }=0.60 \text { for GTAW, } \\
& V=\text { voltage in volts, } \\
& I=\text { current in amperes, } \\
& \nu=\text { welding speed in } \mathrm{mm} / \mathrm{sec} .
\end{aligned}
$$

\subsubsection{Shielding Gases}

Shielding gases are used in GTAW in order to prevent atmospheric contamination of the weld metal. This contamination can produce porosity, weld cracking, scaling and even change in the chemical composition of melted material. Besides shielding gas also has a large influence on the stability of the electric arc. Gases with low ionization potential facilitate the ignition of the electric arc and those with low thermal conductivity tend to increase the arc stability. Argon is the most used GTAW shielding gas. It has low ionization potential and is heavier than air, providing an excellent shielding of the molten weld pool. Furthermore it is less expensive than helium, the other inert shielding gas used in the process. Argon is used in welding of carbon and stainless steels and low thickness aluminum alloys components. For welding thick aluminum work-pieces and other high-conductive materials, such as copper alloys, helium is recommended because it has higher ionization potential than argon, needing higher voltage for arc initiation and maintenance, but producing higher heat-input [25] [26]. The shielding gas flows out of the welding torch, surrounding the hot tungsten and molten weld metal, and displaces the air (oxygen and nitrogen), thus preventing the air, in this way, the air is prevented from having contact with the molten metal or hot tungsten electrode [27]. 
Helium or helium/argon $(30 \%-80 \% \mathrm{He})$ mixtures allow increased welding speed and improved process tolerance. Mixtures of argon with up to 5\% of hydrogen are frequently used in welding of austenitic stainless steels. Hydrogen increases arc-voltage and consequently heat input, increasing weld penetration and weld travel speed, as well as improving weld appearance [25]. Argon/hydrogen mixtures are also used in welding of copper nickel alloys. Argon is also used as back side shielding gas, mainly in welding of stainless steels, aluminum alloys and reactive metals. Flow rates of shielding gases depend on weld thickness, being 4 - $10 \mathrm{l} / \mathrm{min}$ for argon and $10-15 \mathrm{l} / \mathrm{min}$ for helium, because it is lighter than argon, and consequently less effective in shielding purposes [28]. Gases with a purity of $99.995 \%$ are used in welding most of the metals, though reactive materials such as titanium need contaminant level less than $50 \mathrm{ppm}$. The choice of shielding gas is very important as it affects weld penetration depth and surface profile, porosity, corrosion resistance, strength, hardness and brittleness of the weld material [25] [29].

The choice of shielding gas dependent on the working metals and effects on the welding cost, weld temperature, arc stability, weld speed, splatter and electrode life. Argon or Helium may be used successfully for GTA welding applications. For welding of extremely thin material pure argon is used. Argon generally provides an arc which operates more smoothly and quietly. Penetration of arc is less when Argon is used than the arc obtained by the use of Helium. For these reasons argon is preferred for most of the applications, except where higher heat and penetration is required for welding metals of high heat conductivity in larger thicknesses [25] [30] [31]. Argon hydrogen mixture is used for welding of some grades of stainless steels and nickel alloys. Pure helium may be used for aluminium and copper. Helium argon mixtures may be used for low alloy steels, aluminium and copper [32].

\subsubsection{Filler Metal}

Filler metals are generally used for plate thickness above $2 \mathrm{~mm}$, having chemical composition similar to that of the parent material. Filler metal diameter is between 1.6 and $3.2 \mathrm{~mm}$ and in automatic systems is normally added cold from a roll or a coil. Many, but not all austenitic stainless steels can be welded without filler metal and without any further heat treatment. Most of the super austenitic alloys require the use of filler metal to obtain proper corrosion resistance of the weld. Normally, the weld metal is able to meet the minimum yield and tensile strength requirements of the annealed base material. The ductility of the welds is generally lower than base metal, but they are still very ductile. Low carbon grades (L-grades) of filler metals are normally used for corrosion resistant service. For high-temperature service, the higher carbon filler metals may give better high-temperature strength. The compositions of many of the 300 series filler metals are adjusted so that they solidify with a certain amount of ferrite to prevent hot cracking during solidification. This allows for higher heat inputs and thus higher welding speeds. The presence of a certain amount of ferrite means 
that welds are slightly ferromagnetic. Those alloys that solidify fully or nearly fully austenitic must be welded with lower heat inputs. For certain applications, a low ferrite weld metal is desirable, and certain filler metals are produced for that purpose. For most 300 series stainless steels, a nominally matching filler metal is the most common filler metal used [28] [33].

\section{Literature Review}

[34] investigated inert gas tungsten arc welding parameters on the mechanical properties of SS $316 \mathrm{~L}$ weldments. 316 ASS rods of dimensions of $25 \mathrm{~mm}$ diameter and $75 \mathrm{~mm}$ length were used. Current, bevel angles gas volumes inputs were varied at different range of 90,100 and 110 ampere, $60^{\circ} 70^{\circ}$ and $80^{\circ}$ and 1.1, 0.9, 0.71 per litre respectively. Taguchi L-9 orthogonal array technique was used. Results obtained showed that the current of $110 \mathrm{~A}$, bevel Angle of $60^{\circ}$ and a gas flow of $0.71 \mathrm{pm}$ offers the maximum tensile strength. While the minimum tensile strength was obtained with current of $100 \mathrm{~A}$, bevel Angle of $60^{\circ}$ and a gas flow of 0.9 per litre. In addition, sample with the minimum tensile strength gave the maximum micro hardness. They concluded that, as micro hardness increases, tensile strength decreases.

Influence of welding speeds and power inputs on the heat affected zone (HAZ) microstructural characteristics and tensile behaviour of type $304 \mathrm{~L}$ austenitic stainless steel was studied by [35]. The butt joint HAZ square geometry samples were produced using Gas Metal Arc Welding (GTAW) process. Results obtained showed that the microstructures were composed mainly of mixture of austenite and ferrite phases. Variations in volume fraction and grain size of the phases were observed at the different welding speeds and power inputs. Chromium carbide formation and precipitation due to sensitization was seen at the grain boundaries. Optimum ultimate tensile strength (UTS) and yield strength (YS) were obtained for HAZ sample at moderate $(4.5 \mathrm{~mm} / \mathrm{s})$ welding speed, and optimum \% elongation at slow welding speed, and optimum UTS and YS were obtained for HAZ sample at power input of $9.2 \mathrm{KW}$, and optimum \% elongation at $12.00 \mathrm{KW}$. Influence of the welding variables on tensile characteristics in the HAZ was found substantial. [36] investigated the effect of GTA welding current, gas flow rate, thickness of work piece on the bead geometry of AISI $304 \mathrm{~L}$, and reported all the process parameters exhibited high influence on the mechanical properties of the material.

[37] investigated effect of pulse and non pulse current on the mechanical properties of 304 SS. A $3 \mathrm{~mm}$ thick sheet of 304 SS was used for the work, pulsed current at different frequencies of $3 \mathrm{~Hz}, 5 \mathrm{~Hz}$ and $10 \mathrm{~Hz}$ was used. Report obtained revealed microstructure, hardness; tensile characteristics of the weldments were influenced by both non pulse and pulse currents to varying degrees. [38] studied the influence of welding speed on the tensile strength of GTAW 304 $\mathrm{L}$ joint, and reported that penetration depth decreased with the increase of bevel height of single V butt joint. Kang et al., (2009) [25] investigated the effect of al- 
ternate supply of shielding gases on austenite stainless steel GTA welded 304 SS. To this end, both conventional and alternate methods were used. Specimen of 200 lengths, 100 weights and 12 thicknesses was used, and the input parameters used were shielding gas, welding current and welding voltage. Under similar welding conditions, the results obtained revealed that the alternate method with $\mathrm{Ar}$ and $\mathrm{He}$, produced the lowest degree of welding distortion as compared to the conventional methods of $\mathrm{Ar}$ and $\mathrm{Ar}+67 \% \mathrm{He}$. Hence, the alternate method has the possibility of solving the problem of the increase in gas cost and welding distortion.

[39] investigated the effect of TIG pulse rate, pulse frequency, arc travel speed and wire feed rate on tensile and hardness properties of girth welding of SS 304 L. The pipes were welded by using orbital welding machine, ER $308 \mathrm{~L}$ filler wire was used for reinforcement of weld. Results obtained showed that sample welded with 90 A pulse current revealed superior tensile strength and hardness properties. Tensile property of $605 \mathrm{MPa}$, and hardness values of the base metal, HAZ and weld metal were $160 \mathrm{HB}, 114 \mathrm{HB}$ and $99 \mathrm{HB}$ respectively. With increasing pulse current, tensile strength and soundness of joint was observed to increase, maximum strength of the joint was obtained at $2.5 \mathrm{~Hz}$ frequency. And at the arc travel speed of $80 \mathrm{~mm} / \mathrm{min}$, maximum strength and soundness of joint was obtained, but with increasing time for making the joint. Also, as the wire feed rate was increased without increase in current; the strength of joint was reported to decrease.

[40] revealed that welding process relies on an intensely localized heat input, which tends to generate undesired residual stresses and deformations in welded structures, especially in the case of thin plates. Increasing the speed of travel and maintaining constant arc voltage and current will reduce the width of bead and also increase penetration until an optimum speed is reached at which penetration will be maximum. Increasing the speed beyond this optimum will result in decreasing penetration [41] [42]. Increase in welding speed causes 1) decrease in the heat input per unit length of the weld, 2) decrease in the electrode burn off rate, and 3) decrease in the weld reinforcement [42] [43]. Excessive high welding speed decreases wetting action, increases tendency of undercut, porosity and uneven bead shapes and Slower welding speed reduces the tendency to porosity. If the welding speed decreases beyond a certain point, the penetration also will decrease due to the pressure of the large amount of weld pool beneath the electrode, which will cushion the arc penetrating force [44]. With increasing welding speed, power or heat input per unit length of weld decreases with attendant less weld reinforcement and decreased penetration, and with excessive high welding speed, wetting action decreases with increasing tendency of undercut, porosity and uneven bead shapes, slower welding speed reduces the tendency to porosity [45].

[46] investigated the effects by producing the welds on a $1.5 \mathrm{~mm}$ thick plate of $16 \mathrm{wt} \%$ Cr FSS conforming to AISI 430 commercial grade, using GTAW torch in 
argon environment at a heat flux between $1008 \mathrm{~W}$ to $1584 \mathrm{~W}$ and speed between $2.5 \mathrm{~mm} / \mathrm{s}$ and $3.5 \mathrm{~mm} / \mathrm{s}$. The width of the sensitization zone increases with increasing the heat input. The depth of the sensitization zone in the thickness direction is insignificant and it is generally within one half of a millimetre. The use of heat input greater than $432 \mathrm{~J} / \mathrm{mm}$ increases the development of sensitized regions. This level of heat input corresponds to heat fluxes in the range 1008 $1296 \mathrm{~W}$ and welding speed between $3 \mathrm{~mm} / \mathrm{s}$ and $3.5 \mathrm{~mm} / \mathrm{s}$. Under this condition the average cooling time is about $10 \mathrm{~s}$. Most grain attack is restricted to the ferrite-ferrite grain boundaries. The ferrite martensite boundaries do not show visible attack. This indicates that welding condition that promotes the formation of martensite in the HAZ is ideal for the presentation of sensitization.

[35] investigated the effects of welding speeds on the hardness property of type $304 \mathrm{~L}$ austenitic stainless steel heat affected zone (HAZ). Thirty samples were produced, and welded under a range of welding variables to produce butt joint HAZ samples. They reported that hardness property of the HAZ was influenced at varying degrees by the range of welding speeds and power inputs. Optimum hardness property was obtained at fast welding speed of $9.5 \mathrm{~m} / \mathrm{min}$ and $9.20 \mathrm{~kW}$ power input. [47] investigated the effect of various welding parameters on the penetration of GTA welds. Increases in welding speed were found to reduce penetration; however, increases in welding current were observed to increase the penetration in high sulfur (HS) casts and decrease penetration in low sulfur (LS) steels. It was also observed that penetration as a function of increasing linear energy (the heat supplied per unit length of weld) revealed a similar trend with increased penetration in HS casts, but the penetration in LS casts was unaffected by increases in linear energy. Their results support the Burgardt-Heiple proposition that changes in welding parameters on penetration can be explained in terms of their effect, sequentially, on the temperature gradient and the Marangoni forces operating in the weld pool. Increases in arc length were found to decrease weld penetration regardless of the sulfur concentration of the steel, and the effects of electrode geometry and welding position on weld penetration.

[7] studied the effects of various process parameters (welding current, filler materials and groove design) of tungsten inert gas welding (TIG) on aspect ratio, hardness and impact strength of SS304L welded joint. The parameters were optimized using Taguchi orthogonal array (OA) experimental design and other statistical tools such as Analysis of Variance (ANOVA) techniques by Minitab 16 software. Analysis of Variance is used to analyse the influence of parameters during machining. The results obtained indicated that welding parameters have significant influence on impact strength, hardness and Aspect ratio. While hardness and aspect ratio were found to be mostly affected by welding current, impact strength was found to be mostly affected by groove design. [48] carried out analysis of TIG welding process on mechanical properties and microstructure of Aa6063 Aluminum Alloy Joints. To this end, welding current was varied 
and maintaining all parameters constant hardness, impact and tensile strength of the welded joints are tested and finally, microstructure details are analyzed. The results showed mechanical properties linearly varies with increase in weld current.

The effect of heat input, inter-pass temperature, cooling rate, shielding/back purging gas, on corrosion behavior was studied by [49]. DSS and SDSS pipes were welded with Gas Tungsten Arc Welding (GTAW) process. In order to ensure that no flaw was present in the weld, test samples were subjected to non-destructive testing and were prepared for microstructural examinations and ferrite content measurements. And the test samples were subjected to corrosion tests. ASTM G48 test standard was used for the determination of pitting corrosion rate. Potentiodynamic polarization tests and potentiostatic tests were used to verify susceptibility of the alloys to corrosion attack. From the results obtained, they observed that the complex microstructure of root region may have resulted from the repetitive heating of the zone during different weld layers. They reported that desirable microstructure was formed at low heat input. And from the corrosion behaviour results, they reported that DSS weldments had $\mathrm{CPT}$ in between $23^{\circ} \mathrm{C}$ to $27^{\circ} \mathrm{C}$ and SDSS weldments had CPT between $37^{\circ} \mathrm{C}$ to $41^{\circ} \mathrm{C}$ in potentiostatic measurements. The corrosion test results were correlated to the microstructures of the weldments, and the pitting resistance of individual phases was studied and the effect of secondary austenite on corrosion attack was also observed.

Microstructure and mechanical properties of AISI 304 austenitic stainless steels welded by GTA welding was studied by [50]. 308 grade filler metal was used. Microstructures of base metal, heat affected zone and fusion zone were studied with microscopy. Result obtained in the heat affected zone and fusion zone revealed presence of chromium carbide precipitates and dendrite structure, which was reported to have resulted from sensitisation, this finding confirms further that due to sensitisation, unstabilised austenitic stainless steels are characterised by precipitation of a network of chromium carbides.

[51] examined effect of welding current and filler metal types on the percent elongation of $3 \mathrm{~mm}$ thick austenitic steel (304L grade) welded joint. They considered five welding currents in the range of 91 - 95 amperes at 1 ampere interval, and used three types of filler metal namely ER308L, ER309L and ER316Ld to produce square butt weld joints. Standard equipment and ASTM standard procedure were used for determining percent elongation. And reported based on results obtained that percent elongation for all filler metal types increased with increase in welding current, but were generally lower than that of the base metal.

[52] studied the effect of welding on the corrosion resistance of the austenitic stainless steel Alloy 59 (UNS N06027) as well as the galvanic corrosion generated by the base/weld pair estimated from the polarisation curves according to the mixed potential theory. The materials were exposed to polluted phosphoric acid at several temperatures. And the samples' microstructures were studied by SEM and EDX analysis. Based on the results obtained, they reported that the welding 
process shifted the corrosion potential values to more anodic potentials. And due to welding effect, corrosion current densities and the passive current densities were also observed to increase with increasing temperature. Also, they observed that as a result of passivation of material, open circuit potential values were located in the passive zone of the potentiodynamic curves. They reported that galvanic corrosion of the pair was not severe in the studied conditions. The ratio between the galvanic current density of the pair and the corrosion current density of the uncoupled anode was reported to be less than 5 , an implication of compatibility of the members in the couple.

\section{Conclusions}

Based on the review, the following conclusions are drawn:

1) Welding parameters have influence on the mechanical properties (tensile, hardness, impact) of GTA welded joints;

2) Corrosion behaviours of GTA welded joints are influenced by welding parameters in varied degrees;

3) High quality GTA welded joint depends primarily on optimized welding parameters arrangement.

Better economy, improved efficiency and high profitability are some notable derivable advantages obtainable through proper welding input parameters selection.

\section{Conflicts of Interest}

The authors declare no conflicts of interest regarding the publication of this paper.

\section{References}

[1] Benjamin, W.N., Alan, B.D. and Richard, A.W. (1989) Modern Manufacturing Process Engineering. McGraw-Hill College, 627-628.

[2] Ramesh, K.N. and Chauhan, P.M.R. (2014) Mechanical Properties and Microstructural Investigations of TIG Welded $40 \mathrm{~mm}$ and $60 \mathrm{~mm}$ Thick SS 316L Samples for Fusion Reactor Vacuum Vessel Applications. Fusion Engineering and Design, 89, 3149-3158. https://doi.org/10.1016/j.fusengdes.2014.10.006

[3] Dutta, J. and Narendranath, S. (2014) Estimation of Cooling Rate and Its Effect on Temperature Dependent Properties in GTA Welded High Carbon Steel Joints, Welding Journal, 10, 149-155. https://doi.org/10.18488/journal.71/2014.1.2/71.2.55.66

[4] Lee, W.-S., Tzeng, F.-T. and Lin, C.-F. (2005) Mechanical Properties of 304L Stainless Steel SMAW Joints under Dynamic Impact Loading. Journal of Materials Science, 40, 439-484. https://doi.org/10.1007/s10853-005-1920-0

[5] Ghosh, A and Mallik, A.K. (2008) Manufacturing Science. East-West Press Private Limited, New Delhi, 63-68.

[6] Hajinnia, I., Shamanian, M. and Kasiri, M. (2013) Microstructure and Mechanical Properties of AISI 347 Stainless Steel/A335 Low Alloy Steel Dissimilar Joint Produced by Gas Tungsten Arc Welding. Materials and Design, 50, 566-573. 
https://doi.org/10.1016/j.matdes.2013.03.029

[7] Arpita, N.B. and Vikram, A.P. (2016) Influence of Process Parameters of TIG Welding Process on Mechanical Properties of 304LSS Welded Joint. International Research Journal of Engineering and Technology, 3, 977.

[8] Lokesh, K.G., Karthikeyan, P., Narasimma, R.C., Prasanna, B. and George, O. (2015) Microstructure and Mechanical Properties of ASS (304)-FSS (430) Dissimilar Joints in IN SMAW and GTAW Process. International Journal of Engineering Sciences and Research Technology, 6, 367-378.

[9] Kumar, A. and Sundarrajan, S. (2009) Effect of Welding Parameters on Mechanical Properties and Optimization of Pulsed TIG Welding of Al-Mg-Si Alloy. Advanced Manufacturing Technology, 42, 118-125.

https://doi.org/10.1007/s00170-008-1572-8

[10] Subodh, K. and Shahi, A.S. (2011) Effect of Heat Input on the Microstructure and Mechanical Properties of Gas Tungsten Arc Welded AISI 304 Stainless Steel Joints, Materials and Design, 32, 3617-3623. https://doi.org/10.1016/j.matdes.2011.02.017

[11] Sindo, K. (2003) Welding Metallurgy. 2nd Edition, Wiley, Hoboken.

[12] Munoza, A.C., Ruckert, G., Huneau, B., Sauvage, X. and Marya, S. (2008) Comparison of TIG Welded and Friction Stir Welded Al-4.5Mg-0.26Sc Alloy. Journal of Materials Processing Technology, 197, 337-343.

https://doi.org/10.1016/j.jmatprotec.2007.06.035

[13] Lakshman, S., Rohit, K., Nidhi, G. and Mayur, G. (2013) Investigating the Effect of TIG Welding Parameters 5083 Aluminium Alloy Weldability. Materials and Design, 2, 37-44.

[14] Ahmet, D. (2004) Experimental Investigation of the Effect of Hydrogen in Argon as a Shielding Gas on TIG Welding of Austenitic Stainless Steel. Materials and Design, 25, 19-23. https://doi.org/10.1016/j.matdes.2003.07.004

[15] Medvedv, S.V. (2002) Computer Modeling of Residual Welding Strains in Technological Design of Welded Structures. Welding International, 16, 59-65. https://doi.org/10.1080/09507110209549491

[16] Salleh, M.S. (2011) Study on Mechanical Properties and Microstructure Analysis of AISI 304L Stainless Steel Weldments. Journal of Mechanical Engineering Technology, 3, 71-82.

[17] Seo, D.W., Jeon, Y.B. and Lim, J.K. (2003) Effect of Electric Weld Current on Spatter Reduction in Spot Welding Process. Key Engineering Materials, 261-263, 1623-1628.

[18] Atma, R.M.R. and Joy, V.V.M. (2014) Determination of Distortion Development during TIG Welding of Low Carbon Steel Plate. International Journal of Engineering Research, 1, 23-29.

[19] Tewari, S.P., Gupta, A. and Prakash, J. (2010) Effect of Welding Parameters on the Weldability of Materials. International Journal of Engineering Science and Technology, 2, 512-516.

[20] Abioye, T.E. (2017) The Effect of Heat Input on the Mechanical and Corrosion Properties of AISI 304 Electric Arc Weldments. British Journal of Applied Science and Technology, 20, 1-10. http://www.sciencedomain.org https://doi.org/10.9734/BJAST/2017/32846

[21] Chuaiphan, W. and Srijaroenpramong, L. (2013) Effect of Welding Speed on Microstructures, Mechanical Properties and Corrosion Behavior of GTA Welded AISI 201 Stainless Steel Sheets. Journal of Materials Processing Technology, 214, 
402-408. https://doi.org/10.1016/j.jmatprotec.2013.09.025

[22] Janunkar, R.G., Allurkar, S. and Mahesh, P. (2017) An Influence on Effect of Welding Speed on Strength of Welded Joint Using Tig Welding Process. World Journal of Technology, Engineering and Research, 2, 337-342.

[23] Yuri, T., Ogata, T., Saito, M. and Hirayama, Y. (2000) Effect of Welding Structure and $\delta$-Ferrite on Fatigue Properties for TIG Welded Austenitic Stainless Steels at Cryogenic Temperatures. Cryrogenics, 40, 251-259.

[24] Apurv, C. and Vijaykumar, S.J. (2014) Influence of Heat Input on Mechanical Properties and Microstructure of Austenitic 202 Grade Stainless Steel Weldments. WSEAS Transactions on Applied and Theoretical Mechanics, 9, 222-228.

[25] Kang, B.Y., Yarlagadda, K.D., Prasad, V., Kang, M.J., Kim, H.J. and Kim, S. (2009) The Effect of Alternate Supply of Shielding Gases in a Austenite Stainless Steel GTA Welding. Journal of Materials Processing Technology, 209, 4722-4727.

[26] Sun, H., Song, G. and Zhang, L.F. (2008) Effects of Oxide Activating Flux on Laser Welding of Magnesium Alloy. Science and Technology of Welding and Joining, 13, 305-311. https://doi.org/10.1179/174329307X213846

[27] Ghazvinloo, H.R. and Honarbakhsh-Raouf, A. (2010) Effect of Gas Shielded Flux Cored Arc Welding Parameters on Weld Width and Tensile Properties of Weld Metal in Low Carbon Steel. Journal of Applied Science, 10, 658-663. https://doi.org/10.3923/jas.2010.658.663

[28] Arun, N., Cijo, M., Vinod, Y.B. and Joby, J. (2013) Influence of Gas Tungsten Arc Welding Parameters on Aluminum 5083 Alloy. International Journal of Engineering Science and Innovative Technology, 2, 113-118.

[29] Paniagua-Mercado, A.M., Lopez-Hireta, V.M., Mendez-Sanchez, A.F. and Saucedo-Munoz, M.L. (2007) Effect of Active and Nonactive Fluxes on Mechanical Properties and Microstructure in Sub-Merged-Arc Welds of A-36 Steel Plates. Journal of Materials and Manufacturing Processes, 223, 851-863.

[30] Qin, G.L., Wang, G.G. and Zou, Z.D. (2012) Effects of Activating Flux on $\mathrm{CO}_{2}$ Laser Welding Process of 6013 Al Alloy. Transactions Nonferrous Metallurgical Society China, 22, 23-29.

[31] Bang, K.S., Jung, D.H., Park, C. and Chang, W.S. (2008) Effects of Welding Parameters on Tensile Strength of Weld Metal in Flux Cored Welding. Science and Technology of Welding and Joining, 13, 508-514. https://doi.org/10.1179/174329307X249397

[32] Zhang, R., Fan, D. and Katayama, S. (2006) Electron Beam Welding with Activating Flux. Transactions of JWRI, 35, 19-12.

[33] Ibrahim, H. (2013) Study on Microstructure, Tensile Test and Hardness 304 Stainless Steel Jointed by TIG Welding. International Journal of Science and Technology, 2, 23-34.

[34] Balaji, C., Abinesh, K.S.V., Ashwin, K.S. and Sathish, R. (2012) Evaluation of Mechanical Properties of SS 316L Weldments Using Tungsten Inert Gas Welding. International Journal of Engineering Science and Technology, 4, 124-131.

[35] Oyetunji, A., Kutelu, B.J. and Akinola, A. (2013) Effects of Welding Speeds and Power Inputs on the Hardness Property of Type 304L Austenitic Stainless Steel Heat-Affected Zone (HAZ). Journal of Metallurgical Engineering, 2, 124.

[36] Gadewar, S. (2010) Experimental Investigation of Weld Characteristics for a Single Pass TIG Welding with SS 304. International Journal of Engineering Science Technology, 2, 3676-3686. 
[37] Raveendra, S. (2012) Weldability and Process Parameter Optimization of Dissimilar Pipe Joints Using GTAW. International Journal of Engineering Research and Applications, 2, 2525-2530.

[38] Ahmed, K.H., Abdul, L., Mohd, J. and Pramesh, T. (2010) Influence of Welding Speed on Tensile Strength of Welded Joint in TIG Welding Process. International Journal of Applied Engineering Research, 1, 518-527.

[39] Aamir, S., Abdul, A., Muhammad, I., Osama, J.M. and Sagheer, A. (2017) Effect of TIG Welding Parameters on the Properties of 304L Automated Girth Welded Pipes Using Orbital Welding Machine.

[40] Tsann-Shyi, C., Kuang-Hung, T. and Hsien-Lung, T. (2011) Study of the Characteristics of Duplex Stainless Steel Activated Tungsten Inert Gas Welds. Materials and Design, 32, 255-263. https://doi.org/10.1016/j.matdes.2010.05.056

[41] Iordachescu, M., Ruiz, H.J., Iordachescu, D., Valiente, A. and Caballero, L. (2010) Thermal Influence of Welding Process on Strength Overmatching of Thin Dissimiliar Joints. Welding in the World, 65, 201-209.

[42] Muna, K.A., Jalal, M.J. and Abbas, S.A. (2009) Numerical and Experimental Analyses for Effect Welding Currents on Cooling Rates in MMAW Process. Engineering and Technology Journals, 28, 2276.

[43] Tseng, K.H. and Hsu, C.Y. (2011) Performance of Activated TIG Process in Austenitic Stainless Steel Welds. Journal of Materials Processing Technology, 211, 503-512. https://doi.org/10.1016/j.jmatprotec.2010.11.003

[44] Devakumar, D. and Jabaraj, D.B. (2010) Research on Gas Tungsten Arc Welding of Stainless Steel-Overview. International Journal of Scientific and Engineering Research, 5, 39-54.

[45] Afolabi, A.S. (2008) Effect of Electric Arc Welding Parameters on Corrosion Behaviour of Austenitic Stainless in Chloride Medium. AU Journal of Technology, 11, 171-180.

[46] Anuda, M.O.H. and Mridha, S. (2011) Analysis of Sensitization Profile in Medium Chromium Ferritic Stainless Steel (FSS) Welds. Journal of Integrated Engineering, 3, 17-22.

[47] Shirali, A.A. and Mills, K.C. (1993) The Effect of Welding Parameters on Penetration in GTA, Foundations of Material Science Engineering. McGraw Hill, New York, 78-98.

[48] Jaladi, D.S., Manne, V.R. and Srinivas, K. (2015) Analysis of TIG of TIG Welding Process on Mechanical Properties and Microstructure of Aa6063 Aluminium Alloy Joint. International Journal of Recent and Innovation Trends in Computing and Communication, 4, 623-626.

[49] Prabhu, P. and Rajnish, G. (2016) Effect of Welding Parameters on Pitting Behavior of GTAW of DSS and Super DSS Weldments.

[50] Kurt, H.I. and Samur, R. (2013) Study on Microstructure, Tensile Test and Hardness 304 Stainless Steel Jointed by TIG Welding. International Journal of Science and Technology, 2, 164-168.

[51] Okonji, P.O., Nnuka, E.E. and Odo, J.U. (2015) Effect of Welding Current and Filler Metal Types on Macrostructure and Tensile Strength of GTAW Welded Stainless Steel Joints. International Journal of Scientific Research and Engineering Trends, 1 , 9-12.

[52] Bakour, S., Guenbour, A., Bellaouchou, A., Escrivà-Cerdán, C., Sánchez-Tovar, R., Leiva-García, R. and García-Antón, J. (2012) Effect of Welding on the Corrosion 
Behaviour of a Highly Alloyed Austenitic Stainless Steel UNS N06027 in Polluted Phosphoric Acid Media. International Journal of Electrochemical Science, 7, 10530-10543. 